\title{
Historein
}

Vol 15, No $1(2015)$

Revisiting Democratic Transitions in Times of Crisis

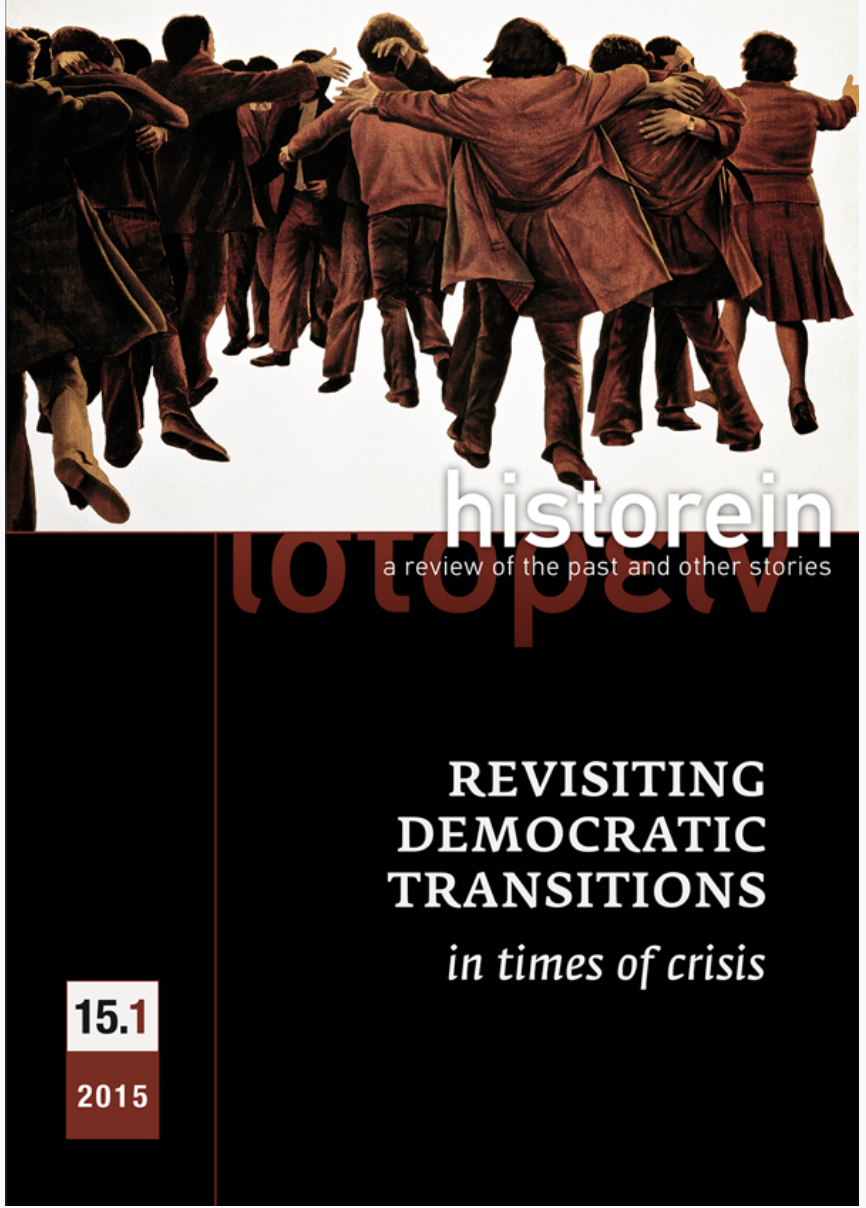

Political economy and the ghosts of the past: revisiting the Spanish and Romanian transitions to democracy

Cornel Ban, Jorge Tamames

doi: $10.12681 /$ historein.274

Copyright $@$ 2015, Cornel Ban, Jorge Tamames

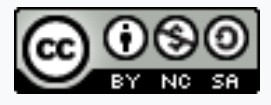

This work is licensed under a Creative Commons Attribution-NonCommercialShareAlike 4.0.

To cite this article:

Ban, C., \& Tamames, J. (2015). Political economy and the ghosts of the past: revisiting the Spanish and Romanian transitions to democracy. Historein, 15(1), 62-82. https://doi.org/10.12681/historein.274 


\section{Political economy} and the ghosts of the past: revisiting the Spanish and Romanian transitions to democracy

Cornel Ban and Jorge Tamames

Boston University and Tufts University
Re-reading the classical books on the liberalisation of authoritarian regimes and/or democratisation is a useful exercise. One of the clearest findings of Juan Linz and Alfred Stepan's Problems of Democratic Transition and Consolidation is that Romania and Spain occupy the extremes of the transition spectrum, with the former as the basket case and the latter as the poster child of successful democratisation. This analysis is based on differences in the scope and quality of democratisation, conditioned by both elite leadership and a series of pre-existing variables such as the nature of the authoritarian regime, the degree of mobilisation within civil society, thresholds of economic development and the existence or lack of established opposition parties or groups.'

This perspective shaped the golden age of transition studies during the 1990s. In this article we argue that in the light of new historical evidence and a more serious look at the political economy of these moments of systemic political change, this perspective needs updating. Indeed, we find that la transición was more contested and contentious than commonly understood by transitologists.

The other claim made by this article is that transitology's inattention to the political economy of transition obscures important insights. The first is that exogenous economic shocks can facilitate the extensive political transformation of an authoritarian regime. Certainly the economic destabilisation of the sociopolitical status quo does not determine such outcomes. Nevertheless, they can create unique opportunities for political action among regime insiders, oppositional elites and mass movements. The second insight is that, given their contestable political legitimacy, postauthoritarian elites that benefit 
from political liberalisation are likely to be cautious about adopting liberal economic reforms without adopting measures that compensate the losers of liberalisation. Spain and Romania look very similar in this regard as well.

The focus on political economy adopted by this comparative analysis of two transition pathways is inspired by the trailblazing work of Stephen Haggard and Robert Kaufman ${ }^{2}$ and, with specific regard to the case of Spain, by the seminal insights of Robert Fishman. ${ }^{3}$ Our contribution to this literature is to highlight more than they do the role of international sovereign debt issues and the economic ideas of local powerbrokers, two aspects that have not received much attention in this rich strand of scholarship.

Specifically, we show that exogenous economic and geopolitical shocks (the 1970s oil crises in the case of Spain and the 1980s debt crisis in the case of Romania) unleashed new political dynamics in both authoritarian systems. For Spain's Francoism, the destabilisation of the status quo was fuelled, first, by the death of Franco and, second, by the social and economic costs of the first oil shock. For Romanian Ceausism it was the combination of the regime's economic ideology, the second oil shock and the debt crisis in much of the Global South, a crisis triggered by the spike in interest rates initiated by the US government.

This article relies on new secondary literature, primary documents and interviews with major transition figures (in the case of Romania). The first section revisits Linz and Stepan's transition spectrum while the second examines the effects of oil crises in Romania and Spain - compounded, in the former's case, by a debt crisis - and their critical contribution to the end of authoritarianism in both countries. The third and fourth sections analyse the political economy of Romania's (19891996) and Spain's (1975-1982) transitions to democracy. A final section draws implications of our findings for the study of transitions to democracy and the relationship between economic crises and political upheaval.

\section{Revisiting the ends of Linz and Stepan's transition spectrum}

Today, both Romania and Spain have relatively presentable, albeit weak democracies, but the once dramatic differences between them seem to have faded quite a lot. Spain's status as a textbook story of transition and consolidation is being shadowed by ongoing events and is being extensively challenged by many Spain scholars and Spanish political and civic actors. Political scientist Simon Tormey spoke for many scholars when he dramatically labelled Spain a "zombie democracy", stumbling around with little sense of legitimacy. ${ }^{4}$ Faced with the avalanche of uncomfortable facts smearing the reputation of Spain's paradigmatic transition, one scholar talked about a transition that was "neither model, nor failure", 5 one euphemistically referred to "institutional degeneration", while another was harsher when he titled his article analysing this malaise thus: "Spain: Corruption, Weak Institutionalization, Unfinished Democratization." Writing at the beginning of the crisis of the eurozone "periphery", Fishman pointed a finger at Spain's elitist transition model for the country's persistent failures in the provision of employment and adequate financing for small firms and welfare benefits relative to the poorer Portugal. ${ }^{8}$ 
Since the outbreak of the 2008 financial crisis, revelations of widespread political corruption in Spain, coupled with catastrophic levels of youth unemployment and the pain accompanying austerity policies, have tarnished the image of the country's establishment to the point that fundamental institutions have seen unprecedented levels of distrust among citizens. ${ }^{9}$ Opinion polls give Spain's leading institutions - courts, parliament and parties - their lowest approval ratings in history. ${ }^{10}$ In lieu of the national unity spirit supposedly sealed during the transition, Madrid now faces a situation in which the northeastern region of Catalonia is taking active steps to secede from the rest of the country. Economic hardship, social unrest and gagging laws have led many to reconsider the supposedly ideal nature of Spanish democracy.

Nothing furnishes proof of this dynamic better than the rise of Podemos, a radical democratic left party that came to lead in the Spanish polls less than a year after it was created, and promises to "break the lock" that the "1978 regime" imposes on Spanish democracy. "While Spanish protest movements were "no longer different from their Western counterparts", ${ }^{12}$ Podemos has tapped into both a source of current frustration towards Spain's political establishment and a broader disaffection towards some of the key institutions of post-Franco democracy.

Things do not look brighter in Romania. Citizens tend to have more confidence in repressive state institutions (anticorruption prosecutors, the military) than in democratically elected bodies. Protest policing has certainly been harsh at times, but not as harsh as in Spain and no gagging laws have been adopted in Bucharest. In 2012, the opposition took power after undermining key democratic institutions such as the ombudsman and trampling over parliamentary procedures.

Writing in 1996, Linz and Stepan were right to be sceptical of the course of democratisation in Romania, a country whose leaders travelled to Madrid in 1990 to take notes about how the Spanish did so well. ${ }^{13}$ Critically, while in Spain the authoritarian regime did not order the repressive apparatus to open fire on protestors, Romania experienced shocking bloodshed. This lent credibility to Linz and Stepan's argument that given Romania's "fundamentally different place" even in the context of communist Eastern Europe, where it had the "weakest organised opposition in the region", it was "virtually impossible" for the country to transition to democracy without bloodshed..$^{14}$ Indeed, even after the dictator died, in 1990-1991 the country's transition was marred by social and ethnic conflicts, often abetted by the state, and public opinion polls showed less support for democracy six years after the end of the authoritarian regime than they did in Spain after the same period of time. Furthermore, the political forces steeped in the structures of the old regime lost the second free and fair elections in Spain, whereas they lost for the first time after the third elections during democracy in Romania. The most dramatic difference was the use of the coal miners by the Romanian government as a quasi-police force that raided protest camps in central Bucharest, terrorised the University of Bucharest's classrooms, committed acts of violence against bearded and bespectacled pedestrians and wreaked havoc on the opposition's offices.

But if one digs deeper and casts a longer-term perspective when comparing Spain's la transición with Romania's tranzitie, the differences seem less striking today than in the mid-1990s, when Linz and Stepan finished their opus. In both countries the insiders of the old regime were the first winners of liberalisation and gradually shed their connections with the past. Spain's first democrat- 
ically elected government was formed by the Union of the Democratic Centre (UCD), which was little more than a Francoist successor party. Despite the fact that the Romanian Communist Party (RCP) had been banned, most analyses of postcommunist parties define the Romanian National Salvation Front (FSN) as a communist successor party. ${ }^{15}$

In both countries, the defining marker of consolidation (the political opposition winning in the polls) took place exactly seven years after the death of the authoritarian ruler. Also, in both countries successive governments failed to deal with the horrific human rights abuses of the authoritarian regime. Ten years after the end of dictatorship in both countries, the judicial branch did not experience any significant turnover and the economic privileges of regime insiders survived. Moreover, in both Spain and Romania key pillars of the repression apparatuses built during the dictatorship managed to reproduce themselves to a relatively similar extent across the terms of several freely elected governments.

In November 1975 it was far from obvious that Spain would become a parliamentary democracy. At the time no political faction, from fascist hardliners to the communist opposition, was strong enough to impose its agenda on all others. But as Josep María Colomer pointed out, the balance of power was tilted in favour of Francoist reformists and those opposition parties willing to negotiate with them. ${ }^{16}$ Because the regime did not collapse following Franco's death, the former held a more powerful position than the latter. As a result, Francoist reformers led the transition in its initial - and ultimately most relevant - stages.

It is common to refer to Spain's political and economic transition as a "double transition". Indeed, Spain's political transition did not occur as a "velvet revolution" in which the outcomes of political liberalisation were shaped by elites alone. Organised workers were highly mobilised during its early stages and played an instrumental role throughout the process, pressuring key actors to take into account their demands and considerations.

Granted, Spain did not experience the radical socialist mobilisation of Portuguese industrial workers and peasants, whose intensity had not been matched in Europe for many decades. ${ }^{17}$ In Romania political violence orchestrated by the state security apparatus was much greater but it was very short-lived, effectively ending once the Ceausescu couple had been executed, with a brief flurry of localised, interethnic violence in 1990 remaining an isolated episode. Between 1976 and 1977, however, Spanish political life was anything but thoroughly peaceful or limited to political elites. As a matter of fact, the elite-engineered reforma pactada took place against the background of political violence, state repression, worker strikes and Basque and Catalan demands for self-government.

In the dominant account of the transition to democracy, "consensus" is the keyword that symbolises the spirit of collaboration between Francoist reformers and a relatively tame opposition. Participants in the process, however, frequently remark that fear was the dominant feeling of the day. ${ }^{18}$ Hagiographies on the subject notwithstanding, the Spanish transition was a violent process, with more than 600 Spaniards murdered for political reasons between Franco's death 1975 and 1986. ${ }^{19}$ The spiral of violence caused by ETA's killings and the extreme right's murders - most notably the Montejurra shootings in May 1976 and the murder of communist lawyers in Madrid in January 1977 
- and harsh government reprisals conditioned the entire process. Wave after wave of assassinations, kidnappings and police shootings ripped through the fabric of Spanish political life between the adoption of political reform laws that gave Spain a multiparty system, and the organisation of the first free and fair elections in 1977, with political killings rising steadily until 1980.

Against this backdrop, the importance of memory and political learning became a critical feature of the Spanish transition. The collective memory of the 1936-1939 civil war haunted elites across the political spectrum as well as most of Spanish society. ${ }^{20}$ As Paloma Aguilar has noted in her landmark study, avoiding a similar bloodbath became an across-the-board imperative. ${ }^{21}$ Ultimately, the necessity for reconciliation led to a collective unwillingness to revisit the past - or rather, a willingness to forget it under a blanket of institutionalised amnesia. No purges of the Francoist establishment took place, and attempts to provide transitional justice went nowhere. When an amnesty law for political prisoners was finally approved in October 1977, it contained two unnoticed paragraphs shielding Francoist officials from "crimes and faults" committed during their mandate. ${ }^{22}$

Strikingly, on some levels of the "transitological" debate, Romania does better than Spain. For all their ills, the founding elections in Romania were organised five months after the death of the dictator; in Spain, this took two years. It is also an overlooked fact that unlike in Romania, where higher-echelon regime insiders were effectively removed from the levers of power within days of the dictator's death, Franco's regime survived his death relatively unscathed. While Spain's first democratic government faced a restive military and an attempted coup d'état in 1981, Romanian governments always had a firm grip on the military. Backed by the EU, in recent years an independent Romanian anticorruption body has jailed a record number of leading politicians, civil servants from all levels of the state bureaucracy and some of the country's wealthiest businesspeople, making the country a model for antigraft campaigners. Spain's extensive corruption has not experienced similar challenges yet.

Finally, in the long term, popular arguments made by transitiologists that post-sultanist Romania would most likely fail to democratise and even slip into ethnic warfare proved to be overstated. If one looks at the state of democracy in Eastern Europe today, it is instead Hungary - once the poster child of Spanish-style pacted transition - that has the greatest struggles with liberal democracy. In lieu of ethnic war, by the early 2000s Romania had one of the most advanced formal systems of protection for ethnic minorities in Europe..$^{23}$ Although at the informal level, Romanian-Hungarian animosities endure due to "separate and opposite views of entitlement grounded in different interpretations of history", ${ }^{24}$ observers agree that this country's progress from violent conflict to interethnic peace and progressive minority rights is one of the most intriguing transformations of recent European history. ${ }^{25}$

One caveat is important at this point. These findings are not meant to excessively downgrade the pacted transition model as it was built in Spain. Bonnie Field and Omar Encarnacion have produced convincing evidence that Spain's Moncloa pacts did not preclude more competitive and representative democratic politics, as initially feared. ${ }^{26}$ Also, intraparty discipline had its dark side, but overall it probably spared Spain some dramatic political troubles.$^{27} \mathrm{~A}$ recent volume edited by Diego Muro and Gregorio Alonso, which brings together leading names in the study of Spanish democratisation studies (Richard Gunther, José Ramón Montero, Ignacio Lago, Bonnie Field, Pablo Sánchez 
Leon), makes a compelling case for not giving up too easily on the virtues of Spain's dramatic political transformation in the late $1970 \mathrm{~s}^{28}$ Our aim is only to contribute to the comparative literature on democratisation by qualifying the extreme contrasts posited by an iconic piece of this literature.

\section{Oil shocks and the end of Francoism in Spain}

Spain, according to Linz and Stepan, as well as a cohort of transitologists following in their footsteps, constitutes "the paradigmatic case for the study of pacted transition and rapid democratic consolidation, much as the Weimar Republic became paradigmatic for the study of democratic breakdown"..$^{29} \mathrm{~A}$ few years earlier, Gunther praised Spain as the ultimate model of transition by elite settlement. ${ }^{30}$ The country had ideal conditions on most variables relevant to the process -a "civilianised-authoritarian regime", relatively strong opposition parties and a civil society that already mirrored Western Europe's, in large measure as a result of the regime's strong economic development throughout the 1960s. ${ }^{31}$ But the path from dictatorship to democracy was not set in stone. While it may have officially began with Franco's death in November 1975, the transition was accelerated by exogenous economic shocks.

However, compared to the severity of Romania's debt crisis and draconian austerity of the 1980s, followed by international policy conditionality in the early 1990s, the final years of Francoism were spent in relative prosperity and the first transition governments maintained their policy autonomy. This gave the Spanish authorities more political options when dealing with the demands made by opposition parties and mobilised citizens.

Ironically, the end of Keynesianism, the great enabler of the golden age of embedded liberalism, coincided with the death of Franco. At the same time, the Spanish government was one of the few European governments that reacted to the October 1973 oil shock by refraining from adopting Keynesian policies, despite the fact that Spain had the highest savings and credit ratings in the Mediterranean. In Spain - the OECD's most notorious oil-guzzler - the attempts made by the central bank and finance ministry to transfer the costs of adjustment to the population facilitated antiregime mobilisation across very different sectors of society once the OPEC price hike began to bite. ${ }^{32}$

The terminal crisis of the Bretton Woods order and Europe's entry into stagflation had immediate repercussions in Spain. As the markets bet aggressively against an overvalued dollar in 1969, they saw incentives in investing in the undervalued currencies of countries with strong growth and low debt like Spain. As a result, Spain saw a boost in credit, inflationary pressures and a deteriorating balance-of-payments sheet. Between 1971 and 1973, Spain's hard currency reserves grew by 500 percent, encouraging more speculation on the peseta. Declaring that the economy was "overheated", the finance ministry intervened to "cool" the upward cycle by increasing the discount rate to the high levels used by France during the late 1960s and early 1970s.

But while Spain's balance of payment figures (with the exception of the current account) saw important surpluses, the high interest rates attracted foreign portfolio investments, which facilitated 
a spectacular inflation growth from 1.6 in 1970 to 8.3 percent in 1971. Before the first oil shock hit, Spain's inflation was at 14 percent, almost double the average of the previous 15 years ( 7.8 percent). ${ }^{33}$ But, like in postwar France, Spain's high inflation was accompanied by high growth rates (almost 8 percent in 1973), full employment and high savings simultaneously. ${ }^{34}$

The economic crisis and the emerging political crisis ignited important reconsiderations at the top of the regime. Unfortunately for the Spanish government, the oil shock of 1973 cost Spain 3 percent of GDP, ${ }^{35}$ put its external deficit in the red for years to come and increased inflationary pressures even further. The economic dislocations were so severe and the situation in post-Caetano Portugal so dramatic that Franco's successors were initially concerned that the status quo would be radically challenged should they not open up the valves of discontent in controlled ways. After a decade of spectacular growth, the regime had a hard time maintaining its base while the crisis set in. Indeed, the Catholic church, under Cardinal Tarancón, had withdrawn its until then steadfast support. ${ }^{36}$ Internal pressure, coupled with the need to find a successor for the aging dictator, posed serious problems for the perpetuation of authoritarian rule. ${ }^{37}$ Yet the regime remained in a position of strength, and the road to democracy was obstructed by an unresolved economic crisis, the absence of a clear opposition leader and a host of other thorny issues that needed to be tackled most notably regional plights for autonomy and widespread violence triggered by ETA.

The regime also faced a young generation of students who had been politicised by the Spanish 1968. As Kostis Kornetis shows, like other Mediterranean countries Spain experienced a diffusion of leftist cultural protest frames and had its youth primed for political contention as a result. Indeed, the country's educated urban youth entered the transition years with a "long 60s" mindset shaped as much by the Western student movements as by the Latin American (and particularly Cuban) leftist experiences. ${ }^{38}$

Unlike in Romania, Spain's dictator died peacefully in his own bed. This turned out to matter a lot more for Spain's political transformation than the ongoing economic crisis. In this climate, mass mobilisation for democracy, coupled with and reinforced by economic discontent, pushed regime insiders towards political liberalisation. As in Romania, Spain witnessed a great deal of social unrest following the adoption of the first political liberalisation measures. The dismantlement of state planning following ETA's assassination of Carrero Blanco, the planners' patron, coupled with Franco's imminent death and growing social unrest increased economic uncertainty for investors accustomed to a stable authoritarian regime. At the same time, this climate strengthened the hand of reformists from the old regime and their critics in the political opposition who claimed that Spanish capitalism did not compensate the losers of the market economy as much as it should. Economic uncertainty was compounded by political uncertainty: with prime ministers and finance ministers changing every year between 1973 and 1977, nobody knew what kind of political regime would emerge. As a result, policymakers postponed potentially disruptive socioeconomic reforms, especially those that risked increases in unemployment or wage cuts.

One of the great but underappreciated insights of Linz and Stepan's volume is that the pivotal elites associated with the old regime (King Juan Carlos and post-Francoist premier Adolfo Suárez) acted out of "fear of a vacuum of authority, of a sudden transfer to the then quite radical opposition 
forces" ${ }^{39}$ The insiders, however, would find their position strengthened by the opposition's tactical mistakes. Its two main parties, the Spanish Socialist Workers' Party (PSOE) and the Communist Party of Spain (PCE), were locked in a struggle to lead the left. The communists underestimated the dictatorship's resilience and expected Franco's regime to collapse following his death..$^{40}$ That this was not on the cards became clear in July 1976, when Suárez became prime minister. Suárez was a regime insider, but also a charismatic reformist who skilfully stole the initiative from the opposition. By the end of the year, a divided and outmanoeuvred left had changed course, shifting its goals from radical rupture with the regime to gradual and pacted reform.

The regime's fears were therefore allayed by hope. Indeed, its elites assumed that economic crisis and democratisation would not lead to the victory of the radical left riding on a wave of socioeconomic frustration, ${ }^{41}$ and that centrist parties would control the Spanish political system. These expectations were based at first on polls showing that the Spanish population was ideologically moderate and committed to democratisation, and that Spanish eurocommunism was not as electorally attractive as it was assumed to be.42 The 1977 elections convinced the insiders that radical parties could not muster much support and that the political formations formed by regime insiders were still popular.

Based on these perceptions, after a year of hesitation, the regime insiders undertook radical alterations of the political system. In the autumn of 1976, the Francoist "parliament" voted to phase itself out by passing a package of political reforms that legalised political parties and trade unions and scheduled the country's first democratic elections for the following year. As predicted, Suárez's UCD - a loose coalition of social and Christian democrats, Francoist nostalgics and liberals grouped around the figure of the prime minister - won and began liquidating the institutions of authoritarianism. After the UCD won the 1977 elections, an intraparty agreement called the Moncloa pacts was brokered by Suárez, committing all political parties to the creation of a new political regime and the liberalisation of the Francoist economic system. ${ }^{43}$ Such an agreement between the democratically legitimised regime insiders and the emerging opposition was not achieved in Romania after the 1990 elections, where political confrontation remained the norm.

\section{Debt crisis, austerity and the end of Ceausism in Romania}

The high degree of power centralisation in Nicolae Ceausescu's family and its "retinue" made some political scientists label his regime as "dynastic socialism" 44 or "sultanism". ${ }^{45}$ Basically, opposition to Ceausescu from within the party-state apparatus could only be clandestine and conspiratorial. This made dissidence ideologically stunted. When formerly high-ranking members of the regime protested in 1988 by having a letter read out on Radio Free Europe (the so-called "Letter of the Six"), they blamed the socioeconomic morass on Ceausescu and his "clique" and called for minimal reforms rather than for reform socialism or perestroika. ${ }^{46}$

What brought down the edifice of Romania's authoritarian regime was the combination of a debt crisis, the ensuing austerity and changes in Moscow's politics. While this country's national-Stalinist developmental state had been consistent with increasing trading, technological and financial 
integration with the capitalist core, its blind spot was growing vulnerability to oil price and financial shocks. Consequently, when the 1979 oil shock struck just as access to international credit was restricted, the regime drove the country into a debt crisis.

As Cornel Ban argues regarding the political economy of Romania's transition, the politics of the debt crisis should be the focus of the debate, albeit on different terms than those advanced by Stephen Kotkin and Jan Gross ${ }^{47}$ For in contrast to other socialist countries that fell prey to the low interest petrodollar loans made available by the 1973 oil crisis, the Romanian debt crisis was the result of overinvestment in oil-guzzling industries and oil-refining capacity. While Hungary and Poland exponentially increased their convertible currency debt between 1973 and 1979, in Romania it was not until 1978 - around the time when interest rates skyrocketed as a result of a change in US monetary policy - that the regime took up a heavy foreign debt burden. It did so to pay for the hard currency bill that accompanied an industry built without careful regard for the price of imported inputs. Faced with the perspective of a sovereign default in 1982, Romania decided to avoid both default and debt restructuring and opted for a harsh austerity policy regime coupled with an original brew of import substitution and export orientation.

The regime's ideological commitment to centrally planned industrialisation and exclusive policy sovereignty was not seen as negotiable, a feature reinforced by the sultanistic nature of its political institutions. As long as the regime was committed to this ideological postulate, it was simply inconceivable that it would acquiesce to the choice made by Poland to avoid dramatic austerity measures in exchange for the intervention of the IMF in its economic affairs. The regime's abandonment of a legitimising strategy, however minimalistic - that is, guaranteeing basic socioeconomic needs was decisive for its collapse in the favourable external environment provided by 1989.

In prioritising sovereignty and industrialisation over material welfare, the regime breached its implicit social contract with industrial workers - the class it had "created" and claimed to represent. This left coercion and national ideology as the only means to keep the masses in check. But since the latter had been undermined by the 1987 Brașov protests, the regime's survival hinged on the smooth functioning of its repressive apparatus. Confronted with mass protests in December 1989, the Ceausescu regime had no choice but to abandon its commanding posts. After a decade of economic repression, the dictatorship imploded: the RCP was banned, Ceausescu was swiftly executed, and his immediate collaborators found themselves serving prison terms after a televised trial.

Soon after the events, the new conventional wisdom that emerged was that, far from a revolution, this was in fact a well-organised coup d'état, with the mass movement acting as an innocent political side-show. In a joint study, two experts on Romania suggested that this interpretation became paradoxically widespread in Romanian political discourse after 1990 in general. ${ }^{48}$ Many transitologists working with secondary sources or whose field interviews were plagued by gatekeeper problems fell victim to this view as well. ${ }^{49}$ But as the most in-depth study of those events concludes,

the mass mobilisation, widespread violence, spontaneous creation of local revolutionary councils, breakdown of the revolutionary coalition and the subsequent fierce struggle between the 
revolutionary contenders on the streets of Romania's cities all would seem to belong to the repertoire of revolution rather than coup d'état. Moreover, even if Ceaușescu had fallen in a coup, this need not have prevented the events in Romania bearing the name revolution. ${ }^{50}$

As the same author suggests, the problem is rooted in the export of a local terminological idiosyncrasy:

The politically inspired reductionism which resulted in the rejection of the Leninist model of revolution in favour of an idealised reading of the liberal variant imposed an impossibly narrow definition of revolution onto the political debate in Romania. Not only did the revolution have to be an entirely spontaneous mass uprising untainted by previous plotting or the meddling of foreign powers, but also the new leadership had to derive from the crowd and be totally unconnected with the previous ruling group. ${ }^{51}$

Like in Spain, the period stretching from the death of the dictator and the founding elections of May 1990 was marked by intense politics at both the elite and mass level. After the overthrow of Ceausescu, popular mobilisation prevented former prime ministers from forming provisional governments, and a group of officials within the RCP who had been marginalised by Ceausescu and a few protest leaders with or without dissident pasts formed the FSN, an organisation that proclaimed itself on television as the new authority in the land.

The leader of the group was lon lliescu, one of the high-ranking reformist RCP officials demoted by Ceausescu during the 1970s and a man who had been expected by Western and some Romanian elite circles to become a Romanian Gorbachev. The FSN council announced the end of the leading role of the sole party, a "democratic and pluralist system of government", free elections, separation of powers, the "deideologisation" of education, human rights, and other liberal reforms.

In sum, unlike the negotiated transitions in Spain, the Romanian authoritarian regime died in a violent fight following the convergence of an unsuccessfully repressed revolutionary movement and a regime breakdown. ${ }^{52}$ Contrary to sceptics' assumptions, it quickly became clear that the high levels of police repression, constant surveillance and the absence of a robust network of antigovernment activists did not prove to be insurmountable obstacles to one of Europe's largest popular revolutionary movements.

The new power structures approximated a Thermidorian reaction, with elements of the ancien regime co-existing alongside transformational social forces. Thus, six of the nine founders of the FSN belonged to the nomenklatura, with one of them (general Ștefan Gușe) being involved in the repression of the protests in Timisoara. ${ }^{53}$ The real power inside the system rested in the council's executive bureau, which was headed by lliescu, who was also appointed as head of state. Likewise, the regional and municipal FSN administrators basically recycled the "second echelon" of the RCP.

At the same time, the FSN formed a provisional government headed by Petre Roman, a 43-yearold French-educated engineering professor who was the son of another dissident RCP figure but was among those who stormed the RCP headquarters. The reformist technocratic elite of Ceaus- 
escu's vast industrialisation complex was also better represented in the executive than aging perestroika figures. ${ }^{54}$ Finally, eight dissident intellectuals were also part of the FSN's national council, yet they were completely outvoted by the other 128 members, and most left the FSN once the council decided to turn it into a political party on 23 January 1990.

This power structure was soon challenged from below by grassroots labour mobilisation. Soon after their formation in many medium and large state enterprises during or in the immediate aftermath of the revolution, workers councils occupied factories and began to act as the soviets promised in the propaganda, calling for the removal of old management and for workers' control of the board. By late January, however, the central FSN headquarters managed to control workers' councils through a series of legislative acts that basically converted them into unions and "NSF councils", respectively, before they began to fade away quickly from the scene.

The role of the Romanian workers' councils as a form of democratised corporate governance remains understudied and their disappearance is one of the most intriguing processes of the revolution, especially as some of the councils proved useful for the January counterdemonstrations against the opposition. One interesting hypothesis is that their increasing autonomy and radical ideas about economic democratisation and participatory democracy were not consistent with the FSN's bureaucratic and technocratic way of doing things. Peter Siani-Davies also suspected that "the continued existence of the NSF councils was incompatible with Western norms and their eclipse was probably sped by pressure from both the opposition and the outside world." ${ }^{n 5}$

After the precommunist (or "historical") political parties (Agrarians, Liberals, Social Democrats) with roots in the precommunist political life re-emerged - often led by people who were politically active in 1949 - the FSN announced its intention to form a political party on 23 January 1990. Its claims to revolutionary legitimacy, combined with its control over the sole TV station, high circulation newspapers and extensive parts of regional and industrial power structures, gave the FSN a crushing electoral advantage in the founding elections of May 1990.

Pending the organisation of the elections, the FSN conservatives abandoned their initial opposition to a multiparty system and acquiesced in the establishment of a provisional parliament in which the front and other political parties had an equal number of representatives. Yet the fragmentation of the opposition (36 parties) gave the front a dominant position inside the provisional parliament. Faced with this situation, the historical parties and their supporters in civil society radicalised their contestation of the FSN through the occupation of Bucharest's main square for weeks on end in what was Eastern Europe's longest street demonstration for liberal democracy.

\section{Democratic consolidation with social compensation in Spain}

When combined with more policy space and a higher degree of labour mobilisation, the Spanish transition was more likely to go smoother because side packages could be offered to those who represented economic frustrations. 
In contrast to Romania, the Spanish labour movement was positioned to extract leverage and project a political voice. Unlike in 1959, when labour repression and a buoyant Western European labour market forced excess labour to leave the country, neither of these two conditions applied by 1976. Jobs were being destroyed throughout Europe at a record pace, forcing governments to restrict migration flows. And, back in Spain, a labour union movement liberated from the worst excesses of the Francoist regime and supported by an emerging political opposition, mobilised and demanded state protection against the vagaries of the market. The fact that the General Union of Workers (UGT) and the Workers' Commissions (CCOO) were respectively linked to the socialist and communist parties enabled them to translate their agenda into specific political platforms using existing institutional arrangements. In Romania, the mosaic of free labour union confederations that emerged quickly after the revolution was keen to stay away from explicit connections to political parties, a choice that ultimately weakened their leverage.

Franco's death also unleashed a wave of strikes throughout Spain. Labour unions had a strong dossier in this regard. During the 1960s, Spanish workers, and especially the CCOO, defied repression and organised strikes at a rate that fell within the Western European spectrum of the time..$^{56}$ José María Maravall's classic study of the Spanish transition found that, by the early 1970s, this pressure developed in a crucial direction by weakening the authoritarian regime's desperate move to open the door to limited liberalisation and evolve into a dictablanda:

popular pressure "from below" ... especially that coming from the workers' movement ... was a causal factor in the Francoist crisis, in the non-viability of any mere "liberalisation" policy, in the willingness on the part of the "democratic right" to negotiate the transition and carry through reform up to the point of breaking with Francoism, and in the initiative displayed by the left up to the 1977 elections. ${ }^{57}$

With an eye on the situation in Portugal, Suárez knew that labour could ruin the chances of a comprehensive political pact, so he cultivated labour assiduously, while shunning capital. His memoirs show that organised business learned about the outcome of the Moncloa negotiations only hours before they were released to parliament. Consequently, business declared the Moncloa pacts as "unreal and unjust", as "evidence that the government was executing a socialist programme", and pulled its political support from UCD.

While the repression of labour mobilisation under Francoism had prevented coordinated action, coordinated industrial conflict would occur virtually unimpeded after 1975. Although the Spanish workers' protest repertoire did not include Portuguese-style occupations of agricultural and industrial property, they outdid their Portuguese counterparts in terms of strike mobilisation. Studies of labour activism recorded an "explosion" in industrial conflict between 1976 and 1979, ${ }^{58}$ with over 3.6 million strikers registered in 1976 (up from 1 million in 1975). ${ }^{59}$ The number of working hours lost through strikes quadrupled from 1975 to 1976. But as Fishman's classic study of plant-level Spanish labour suggests, workers were not ready to go beyond strikes and generally supported elite pacts as the main avenue of democratisation. Both the CCOO and UGT had good reasons not to fear that their interests would be left unrepresented in the party elite negotiations of the late 1970s, as the links between these unions and their parties were especially strong during that period. ${ }^{60}$ 
After almost half a century, Karl Polanyi's pendulum seemed to swing back to (re)embedding the market through more redistribution and "voice". For a while, it seemed that labour would be able to force open the historical window to "embedded liberalism". ${ }^{61}$ As Portugal witnessed mass expropriations and a collapse of the ancien regime, the post-Francoist ruling elites had every reason to be cautious. The result of their fear of social unrest was the adoption of expansionary macroeconomic policies in 1976, largely in the form of credit issued by public banks and targeted at high-employment housing and capital goods sectors. This new policy stance earned elites enough social peace to weather the challenges of the political transition and led to an extra percentage of growth in GDP, yet played havoc with the conservative inflation-targeting ambitions of the central bank.

Once it became clear that democratisation was "the only game in town" and the post-Francoists won the founding elections of 1977, the liberal reforms launched in the early 1970s were resumed, this time by a government staffed by the most liberal elements of the Franco regime. The new "superminister" for the economy, Enrique Fuentes Quintana, understood that since the government could no longer resort to violence to quell demands for wage indexation, the only available solution was a negotiated stabilisation package. The resulting policy package contained in the Moncloa pacts mixed liberal measures, such as trade liberalisation, financial liberalisation, an orthodox stabilisation plan (currency devaluation, tight monetary policy, wage increases well below inflation rates), with more redistributionist measures, such as tax increases and increased welfare expenditures. Indeed, the government made taxation more progressive and raised state revenues by six percentage points to pay for the expansion of the safety net. This mix was less orthodox than the liberal post-Francoists had wanted, but, as Suárez stressed:

in other times the economic measures agreed upon by the cabinet would have been enough to drastically change the course of the economy. But now they have not been as efficient as one might have expected and this owes to the impact of politics on our economy. So long as a country is haunted by unknown quantities of politics, the economy cannot be reactivated or stabilised. ${ }^{62}$

Labour pressures also led to a dramatic modernisation of the Spanish welfare state. Social spending as percentage of GDP grew by 50 percent between 1975 and 1982. ${ }^{63}$ While spending on public goods and economic services in Spain remained stable or even fell as a proportion of GDP after the mid1970s, both expenditure groups showed a marked increase between 1975 and 1982, with spending on general public services growing the fastest. Within this category, welfare spending and subsidies to high-employment private and public companies grew the most. Real compensation for unemployment benefits grew. To pay for some of the growth of these expenses, the government "Europeanised" the tax system by making it more progressive. It also increased the tax burden by one percentage point of GDP per annum between 1977 and 1982, with most of the growth being concentrated on high income earners. The new tax legislation imposed extraordinary surcharges on company profits, luxury goods and very high personal incomes, introduced an "extraordinary net wealth tax", abolished confidentiality in bank operations, and criminalised tax evasion. As a result of these measures, the GDP share on taxes and income rose by 7.6 percent in 1978, almost double the 1975 figure. ${ }^{64}$

Finally, if collective bargaining took place de facto at the factory level during the Franco years, national level bargains became the rule during the late 1970s. The UCD governments also con- 
strained the hire-and-fire freedom of employers by passing a new labour code. For the first time since the civil war, it seemed that a Spanish government reacted to social unrest by incorporating labour into economic decision-making. Yet unlike in the Republican period of the 1930s, labour entered the policy process through a combination of contentious registers (strikes, direct action) and an emerging democratic corporatist institutional infrastructure, rather than outright confrontation.

\section{Democratic consolidation without social compensation in Romania}

Like its Spanish counterpart, Romania's first transition government was as serious about the virtues of social compensation as an appropriate supportive policy for locking in the country's democratic path. The difference with Spain is that this strategy was harder to pursue given the domestic and international conditions of the postcommunist transition.

Indeed, the announced policy priorities of the FSN council suggested a few vaguely formulated measures that could be associated with Gorbachevite reform socialism: the restructuring of the economy in accordance with the criteria of profitability and efficiency, the end of "administrative-bureaucratic methods of centralised economic management" and the fostering of "free initiative and competence" in the management of all economic sectors. The relative stabilisation of political life that followed the violent days of December 1989 changed little in this overall dynamic.

Rather than proceed with Polish-style "shock therapy" or even with the more "gradualist" Hungarian or Czechoslovak reforms, the provisional government adopted instead a limited liberalisation programme: the dismantlement of central planning, partial land restitution, the selective liberalisation of trade, and the legalisation of private enterprises. Other measures suggested mere concern with winning the founding elections. Thus, despite near-zero unemployment and falling productivity, the workweek was reduced to five days, wages were increased across the board and the state's meagre hard currency reserves were spent on long-denied imports of consumer goods.

During the first few months of 1990 , the front did not assert a clear ideological stance on the economy. In January 1990 Silviu Brucan, the FSN's éminence grise, labelled the front "a political organisation without a defined ideology" but then added that "the only ideological label that can be considered for the front is that it situates itself on the left, in the very wide sense given to this word". 65

Brucan was right. The basic elements of a local translation of reform socialism can be detected in the public statements made by lliescu and the provisional government's economic ministers. For example, Iliescu's New Year's speech and the first public statement of the ministers of the economy and industry did not mention market reforms and were limited to the main pillars of the perestroika laws adopted by the USSR in 1987 and 1988: decentralisation of economic decision-making, restructuring as an alternative to liquidation, the end of "megalomaniac investments", and the elimination of price controls in farmers' markets. ${ }^{66}$ Private ownership in the services, small manufacturing and foreign trade sectors also became acceptable. 
The search for "a third way between plan and market" and a vocal critique of Polish "shock therapy" characterised the press interviews given by economic ministers. ${ }^{67}$ Iliescu's initially radical resistance to market reforms was also strongly suggested by the fact that, while the RCP was banned on 11 January 1990,68 it was claimed that in December 1989 his first option for prime minister was Ilie Verdeț, one of Ceausescu's premiers during the 1970s. It was only following pressures from Brucan that Iliescu ended up appointing Petre Roman, a young academic invested with much symbolic capital from entering the party headquarters and proclaiming the end of dictatorship from the balcony. Basically it was only in the spring of 1990 that lliescu and provisional government ministers began to refer more frequently to the transition from the command economy to the "social market economy".

The first Romanian postcommunist government (1990-1992) was only partly committed to adopting the main policy recommendations of the Washington Consensus. As its reforms led the country into a recession whose deleterious effects were unique in peacetime, a heterodox backlash under the second freely elected postcommunist government (1992-1996) sought a third way between neoliberal orthodoxy and reform socialism.

But this policy of social compensation was heavily constrained by international policy coercion. In effect, the IMF and World Bank had a great say in the Romanian policy process since until 1994 Romania had no access to capital markets due to the reputation costs incurred by the former dictator's conflict with sovereign bond investors. ${ }^{69}$ Using a monetarist theory of prices, IMF experts dealing with Romania linked prices to the broad money supply and inflation to excess demand. Therefore the fund asked the government to liberalise industrial prices and to cheapen imports by devaluing the currency. ${ }^{70}$ This rendered firms unable to pay their suppliers, sending the level of intercompany arrears to 40 percent of their turnover. Credit contracted dramatically, leading to chain bankruptcies, while wage purchasing power collapsed after prices were liberalised in an economy marred by a high degree of monopoly and oligopoly. Over the next few years, almost one in every two jobs disappeared for good. When governments tried to stop the meltdown, though the monetisation of intercompany arrears or the slowdown of privatisation, the IMF would suspend the stand-by agreement.71

Similarly, the World Bank's loan programme from June 1991 provided financing for a list of critical imports in exchange for the Romanian government's agreement to use Western experts in the privatisation programme, a modest constraint on the government's independence. But these loan conditions multiplied suddenly in June 1992. In exchange for $\$ 400$ million, the cabinet committed to a laundry list of macroeconomic and structural reforms, leading to the removal of some of the cabinet's neodevelopmentalist reforms such as mark-up caps, export restrictions and the large share of unprivatisable regies autonomes (state-owned firms in areas deemed essential such as utilities, transportation, etc.) in the public sector. ${ }^{72}$

The IMF's decision to suspend its fourth standby agreement four months before the 1996 general elections helped the domestic dynamics that pulled the plug on this grafting exercise. Since the political opposition was generally aligned with neoliberal transition economics, this looked like a controversial investment of the fund in domestic politics. ${ }^{73}$ In a country where Westernisation was a popular electoral platform in urban areas, the opposition's chances of winning increased dra- 
matically after it became clear that Romania's application to join the EU stood no chance due to the lack of the IMF's imprimatur.

After the ex-communists lost the 1996 elections, a centre-right coalition announced that the economic growth achieved by the left-leaning Vacaroiu government (1992-1996) was unsustainable and initiated a "shock therapy" neoliberal reform in which both domestic and external audiences invested exaggerated expectations. Ironically, the official consolidation of democracy came in the same package, terminating most attempts at social compensation as a political strategy. The socioeconomic results of this reform, worsened by the East Asian crisis and the Kosovo wars, were much worse than the reformists expected and consequently the coalition was swept out of office in the 2000 elections. Back in office and pressed by EU integration, the ex-communists embarked on the most systematic and successful economic reforms seen since 1990. In four years, they adopted most of the standard market institutions of the Western European "third way" and even outdid their Western peers by adopting highly regressive right-libertarian tax reforms that both the EU and the IMF criticised.

\section{Conclusion}

Revisiting the comparison of Spain and Romania's transitions to democracy calls for a reassessment of Linz and Stepan's framework. In spite of significant differences in the structure and breakdown - or, in the Spanish case, dismantlement - of their respective authoritarian systems, Spain and Romania experienced transitions to democracy guided by remnants of the old regime. In both cases, regime insiders directed the democratisation process in its initial and ultimately most meaningful stages. This dynamic produced critical repercussions, lasting beyond the stage of democratic consolidation. While exploring the long-term effects on the political economy of the Spanish and Romanian transitions remains beyond the scope of this article, current events suggest that democratisation processes produce long-term effects that the literature on democratic transition, with its focus on short-term dynamics and its end-goal in democratic consolidation, has failed to take into account.

Spain and Romania's transitions also exemplify the importance of economic developments both before and during transitions to democracy. The overlooked contribution of the 1970s oil shocks and the subsequent debt crisis to the termination of authoritarian rule calls for an increased focus on the role of economic shocks and crises as catalysts of sweeping political change. Moreover, access to sovereign bond markets and the absence exposure to international policy conditionality meant that Spanish governments could use social compensation as a strategy of political democratisation in times of economic stress, while their Romanian counterparts were much more constrained in this regard. The importance of these international political economy factors also suggests that, in spite of Linz and Stepan's stress on the importance of individual agency during transitions to democracy, world-systemic dynamics often play a critical role in these processes.

Scholars of democratic transitions can take note of these findings and apply them in further research. While our analysis stretches from the period preceding the demise of authoritarianism to 
that of democratic consolidation, comparative research on the subsequent development of the Spanish and Romanian political economies can yield relevant findings. The prospect of European integration also played a critical role in both transitions to democracy, on both a political and economic level. The crisis within European institutions induced by the 2008 financial crisis has now challenged aspects of the alleged achievements of both transitions, and therefore offers extensive ground for research for prospective researchers. Last but not least, comparative studies between other transitions that occupy different places in the Linz and Stepan canon can be useful in challenging an overly taxonomic - or even taxidermic - approach to the question of democratisation.

\section{NOTES}

1 See Juan J. Linz and Alfred C. Stepan, Problems of Democratic Transition and Consolidation: Southern Europe, South America, and Post-communist Europe (Baltimore: John Hopkins University Press, 1996).

2 Stephan Haggard and Robert R. Kaufman, "The Political Economy of Democratic Transitions," Comparative Politics 29/3 (1997): 263-283; Stephan Haggard and Robert R. Kaufman, The Political Economy of Democratic Transitions (Princeton: Princeton University Press, 1995); Stephan Haggard and Robert R. Kaufman, eds., The Politics of Economic Adjustment: International Constraints, Distributive Conflicts, and the State (Princeton: Princeton University Press, 1992).

3 Robert M. Fishman, "Rethinking the Iberian Transformations: How Democratization Scenarios shaped Labor Market Outcomes," Studies in Comparative International Development 45/3 (2010): 281-310.

4 João França, “Simon Tormey: 'en España hay una democracia zombie'," El Diario, 31 Mar. 2013, accessed 28 Apr. 2015, http://www.eldiario.es/catalunya/Simon-Tormey-Espana-democracia-zombie_0_116888525.html.

5 Álvaro Soto Carmona, "Ni modélica ni fracasada. La transición a la democracia en España," Índice Histórico Español 125 (2012): 117-156.

6 Sebastián Royo, "Institutional Degeneration and Economic Crisis: The Case of Spain," paper presented at the 2014 annual meeting of the American Political Science Association, Washington DC, 28-31 Aug. 2014.

7 Francisco Cardona, "Spain: Corruption, Weak Institutionalization, Unfinished Democratization," Public Administration Review 73/1 (2013): 95-96.

8 Fishman, "Rethinking the Iberian Transformations."

9 Jonathan Hopkin, "Clientelism, Corruption and Political Cartels: Informal Governance in Southern Europe," in International Handbook on Informal Governance, eds. Thomas Christiansen and Christine Neuhold (Cheltenham: Edward Elgar, 2012), 198; Cardona, "Spain: Corruption”; Marcos González-Fernández and Carmen González-Velasco, "Shadow Economy, Corruption and Public Debt in Spain," Journal of Policy Modeling 36/6 (2014): 1101-1117.

10 For a short summary, see José Ramón Montero, "No es el descontento, es la desafección," El País, 14 Jun. 2013, accessed 28 Apr. 2015, http://elpais.com/elpais/2013/06/11/opinion/1370978768_828729.html.

11 Álvaro Carvajal, “Iglesias avisa de que romperá el 'candado' de la Constitución," El Mundo, 16 November 2014, accessed 27 Mar. 2015, http://www.elmundo.es/espana/2014/11/15/5466a2c522601d2e5d8b456f.html. 
12 Susana Aguilar and Eduardo Romanos, "Is Spain Still Different? Social Movements in a Belated Western European Democracy," in Social Movements Studies in Europe: State of the Art (New York: Berghahn, forthcoming).

13 Diego Muro and Gregorio Alonso, eds. The Politics and Memory of Democratic Transition: The Spanish Model (London: Routledge, 2011), 2.

14 Linz and Stepan, Problems.

15 See Vladimir Tismaneanu, “The Legacy of Perestroika," Orbis 38/3 (1994): 505-509; Grigore Pop-Eleches, "A Party for All Seasons: Electoral Adaptation of Romanian Communist Successor Parties," Communist and Post-Communist Studies 41/4 (2008): 465-479. After the FSN's splinter in 1992, this label was generally applied to the more economically leftist PDSR (relabelled PSD in 2000), while Roman's Democratic Party (PD) was considered a successor party only by some (Tismaneanu, "The Legacy of Perestroika"; Pop-Eleches, "A Party for All Seasons.") This institutional continuity at the political level was not a Romanian idiosyncrasy, as "even the more hard-line faction of the FSN, which aligned itself with Mr lliescu against Roman's reformers, actually had lower levels of personnel continuity with second- and third-echelon Communist Party officials than their Hungarian counterpart" (Pop-Eleches, "A Party for All Seasons," 469).

16 Josep María Colomer, La transición a la democracia: el modelo español (Barcelona: Anagrama, 2008), 198.

17 In 1975 in less than a year, Portuguese workers seized more than 23\% of Portugal's farmland, 940 industrial enterprises, and 10,000 houses. The new regime purged the state of both hardliners and centrists, and the constitution of Portugal promised a "classless society" and the "transformation of capitalist relations". The communists had a strong presence in governments, and Portugal came close to pulling out of Nato. Faced with this situation, the US considered covert military action against the new regime (Nancy Bermeo, "Myths of Moderation: Confrontation and Conflict during Democratic Transitions," Comparative Politics 29/3 (1997): 308-309).

18 See Juan Luis Cebrián, La España que bosteza (Madrid: Taurus, 1981), 3.

19 Violence was mainly perpetrated by the extreme right and Basque terrorists, which "fed off each others' blood-lust". Paul Preston, The Triumph of Democracy in Spain (London: Methuen, 1986), 142. See also Mariano Sánchez Soler, La transición sangrienta: una historia violenta del proceso democrático en España (1975-1983) (Barcelona: Península, 2010).

20 Colomer, La transición a la democracia, 174-175.

21 Paloma Aguilar, "Collective Memory of the Spanish Civil War: The Case of the Political Amnesty in the Spanish Transition to Democracy," Estudios/Working Paper 85, Juan March Institute: Center for Advanced Study in the Social Sciences (CEACS), 1996; Paloma Aguilar, Memory and Amnesia: The Role of the Spanish Civil War in the Transition to Democracy (New York: Berghahn, 2002).

22 Paloma Aguilar, "La justicia transicional en los casos español, argentino y chileno", paper presented at the international conference on "Building a Future on Peace and Justice", Nuremburg, 25-27 Jun. 2007.

23 See Ronald H. Linden, "Putting on their Sunday Best: Romania, Hungary, and the Puzzle of Peace," International Studies Quarterly 44/1 (2000): 121-145; Mihaela Mihailescu, “Dampening the Powder Keg: Understanding Interethnic Cooperation in Post-Communist Romania (1990-1996)," Nationalism and Ethnic Policies 11/1 (2005): 25-29; Stephen L. Burg, "NGOs and Ethnic Conflict: Lessons from the Work of the Project on Ethnic Relations in the Balkans," Negotiation Journal 23/1 (2007): 7-33; and Judith J. Kelley, Ethnic Politics in Europe: The Power of Norms and Incentives (Princeton: Princeton University Press, 2006). 
24 Alina Mungiu-Pippidi, Transilvania subiectiva (Bucharest: Humanitas, 1999), 184.

25 Moreover, the institutions of minority representation in the country meet reasonably high standards. A recent study anchored in a systematic analysis of institutions demonstrated that, contrary to conventional wisdom, ethnic minorities are even overrepresented in the Romanian parliament due to the adoption of electoral institutions that the literature recommends for ethnically diverse societies. See Oleh Protsyk and Marius Lupsa Matichescu, "Clientelism and Political Recruitment in Democratic Transition: Evidence from Romania," Comparative Politics 43/2 (2011): 207-224.

26 Bonnie N. Field, “De-Thawing Democracy: The Decline of Political Party Collaboration in Spain (1977 to 2004)," Comparative Political Studies 38/9 (2005): 1079-1103; Omar Encarnación, "Do Political Pacts Freeze Democracy? Spanish and South American Lessons," West European Politics 28/1 (2005): 182203.

27 Bonnie N. Field, "Interparty Consensus and Intraparty Discipline in Spain's Transition to Democracy," in The Politics and Memory of Democratic Transition: The Spanish Model, eds. Gregorio Alonso and Diego Muro (New York: Routledge, 2011), 71-91.

28 Muro and Alonso, eds., The Politics and Memory.

29 Linz and Stepan, Problems, 87.

30 Richard Gunther, "Spain: The Very Model of the Modern Elite Settlement," in Elites and Democratic Consolidation in Latin America and Southern Europe, eds. John Higley and Richard Gunther, 38-80 (Cambridge: Cambridge University Press, 1992).

31 Ibid. The main challenge, the authors point out, was Spain's "stateness" problem - that is, Catalan and Basque demands for self-government, coupled with political violence in the latter's case.

32 In 1973, Spanish imports of oil accounted for almost 70\% of energy consumption. As late as 1978, the import of oil represented $28 \%$ of total Spanish imports.

33 Although the decision of the US to go off gold and devalue the dollar created incentives for even tougher market speculation on the peseta, the authorities decided to defend the currency by maintaining the peseta-dollar peg, thus resisting the worldwide trend towards the managed float regime.

34 In 1973 Spain had a real growth rate of $8 \%$, unemployment at $2 \%$ and a record $\$ 6$ billion in hard currency reserves.

35 At $67 \%$ of the total energy consumption, Spain's oil dependence was higher than the OECD average.

36 By then former falangists like Pedro Laín Entralgo and Dionisio Ridruejo had joined the democratic opposition, and the liberalising elements within the dictatorship, with Manuel Fraga and José María de Areilza at their head, had grown in strength.

37 Prince Juan Carlos was proclaimed Franco's successor as head of state in 1969. At the same time, the government would remain under the control of Franco's long-time right hand, Admiral Carrero Blanco. On 20 Dec. 1973, ETA dealt a huge blow to the regime's chances of continuity by assassinating Carrero Blanco.

38 Kostis Kornetis, "'Cuban Europe'? Greek and Iberian tiersmondisme in the 'Long 1960s'," Journal of Contemporary History 50/3 (2015): 486-515.

39 Linz and Stepan, Problems, 92.

40 Ferrán Gallego, El mito de la transición: La crisis del franquismo y los orígenes de la democracia, 19731977 (Barcelona: Crítica, 2008), 79-80. 
41 Bermeo, "Myths of Moderation," 317-318. For an extensive account, see Linz and Stepan, Problems, 108.

42 Share, Don, “Spain: Socialists as Neoliberals," Socialist Review 1 (1988): 38-67.

43 Linz and Stepan, Problems.

44 Vlad Georgescu, "Romania in the 1980s: The Legacy of Dynastic Socialism," East European Politics and Society 2/1 (1987): 69-93.

45 Linz and Stepan, Problems; Houchang E. Chehabi, "The Political Regime of the Islamic Republic of Iran in Comparative Perspective," Government and Opposition 36/1 (1991): 44-70. For an in-depth analysis of the institutional structure of Romanian national Stalinism, see Stelian Tanase, Revolutia ca esec: elite si societate (lasi: Polirom, 1996).

46 For an assessment of the Letter of the Six, see Vladimir Tismaneanu, The Revolutions of 1989 (London: Routledge, 1999). In essence, "bitter critics of the personal dictatorship, they never questioned the legitimacy of the party's monopoly on power ... There was no liberal faction within the RCP, no group of individuals whose belief-system and mindset would have been informed by the logic of Marxist revisionism. At best, there were private conversations in which individuals were deploring certain 'exaggerations' and 'distortions'." For an in-depth story of one of the writers, see Silviu Brucan, Social Change in Russia and Eastern Europe: From Party Hacks to Nouveaux Riches (Westport: Praeger, 1998).

47 See Cornel Ban, “Sovereign Debt, Austerity and Regime Change: The Case of Nicolae Ceausescu's Romania," East European Politics and Societies 26/ 4 (2012): 743-776, and Stephen Kotkin and Jan Gross, Uncivil Society: 1989 and the Implosion of the Communist Establishment (New York: Modern Library, 2010).

48 Katherine Verdery and Gail Kligman, "Romania after Ceausescu: Post-communist Communism?", in Eastern Europe in Revolution, ed. Ivo Banac (Ithaca: Cornell University Press, 1992), 117-147.

$49 \quad$ Linz and Stepan, Problems.

50 Peter Siani-Davies, The Romanian Revolution of December 1989 (Ithaca: Cornell University Press, 2005), 268 and 277.

$51 \quad$ Ibid., 277.

52 Given the incentives for obscuring evidence, research on the Romanian revolution demands an unusual mix of investigative journalism and social science, and therefore the building of a well-evidenced narrative about it is notoriously difficult (Alina Mungiu-Pippidi, "Doubtful Revolutions and Counter-revolutions Deconstructed," Journal of Southern Europe and the Balkans Online 8/1 (2006): 109-112). The description of the December 1989 events made in this research includes only elements that are not subject to controversy. For the most extensive academic account in English of the Romanian sources, see Siani-Davies, The Romanian Revolution.

53 See the list of the founding members of the FSN council, Romania libera, 27 Dec. 1989.

54 Although 20 out of the 31 ministers were a part of the former communist elite, the most numerous were two categories that suggested a more reformist profile: second-generation technocrats with no RCP positions (Nicolae Ceausescu, Nicolae Stefan, Adrian Georgescu, Gheorghe Caranfil, loan Chesa, Victor Murea, Nicolae M. Nicolae, Corneliu Burada, Dan Enachescu, Sergiu Celac) and technocrats who also followed a career in the party and kept their positions within the state apparatus until 1989 form a second category (Teofil Pop and Nicolae Dicu, Stelian Pintelie, loan Folea). The first Romanian government had only three high-ranking RCP officials marginalised by Nicolae Ceausescu in the 1980s (Nicolae Militaru, Constantin Popescu, Mircea Angelescu). 
56 Robert M. Fishman, "The Labor Movement in Spain: From Authoritarianism to Democracy," Comparative Politics 14/3 (1982): 283.

57 José María Maravall, The Transition to Democracy in Spain (London: Croom Helm, 1982). For a similar thesis that puts Spain in comparative perspective, see Ruth Berins Collier and James Mahoney, "Adding Collective Actors to Collective Outcomes: Labor and Recent Democratization in South America and Southern Europe," Comparative Politics 29/3 (1997): 285-303.

58 Collier and Mahoney, "Adding Collective Actors."

59 Bermeo, Myths of Moderation, 309-310.

60 Sebastián Royo, "The Collapse of social Concertation and the Failure of Socialist Economic Policies in Spain," South European Society \& Politics 6/1 (2001): 27-50.

61 John Gerard Ruggie, "International Regimes, Transactions, and Change: Embedded Liberalism in the Postwar Economic Order," International Organization 36/2 (1982): 379-415.

$62 A B C, 11$ Sept. 1976.

63 Ana Guillen and Manos Matsaganis, "Testing the 'Social Dumping' Hypothesis in Southern Europe: Welfare Policies in Greece and Spain During the Last 20 years," Journal of European Social Policy 10/2 (2000): 128.

64 Francisco de Castro and Pablo Hernández de Cos, "The Economic Effects of Fiscal Policy: The Case of Spain," Journal of Macroeconomics 30/3 (2007): 1005-1028.

65 Interview with Silviu Brucan in Adevarul, 10 Jan. 1990.

66 Iliescu's and economy minister's statements are in Adevarul, 4 Jan. 1990. The industry minister's statement can be found in Adevarul, 10 Jan. 1990.

67 Interview with Mircea Cosea, Adevarul, 16 Jan. 1990.

68 Adevarul, 12 Jan. 1990.

69 Ban, "Sovereign Debt."

70 Dimitri G. Demekas and Mohsin S. Khan, The Romanian Economic Reform Program (Washington: International Monetary Fund, 1991).

71 Cornel Ban, interview with central bank official, 12 Jan. 2009.

72 Liliana Pop, Democratising Capitalism? The Political Economy of Post-communist Transformations in Romania, 1989-2001 (Manchester: Manchester University Press, 2006), 129.

73 Daniela Gabor, "Paradigm Shift? A Critique to the IMF's New Approach to Capital Controls," Economics Discussion Paper Series No 11/09, School of Economics, University of the West of England, Bristol, 2011, accessed 28 Apr. 2015, http://carecon.org.uk/DPs/1109.pdf. 